\title{
DAMPAK PAPARAN PORNOGRAFI PADA ANAK USIA DINI
}

\author{
Trinita Anggraini ${ }^{1}$, Erine Nur Maulidya ${ }^{2}$
}

\author{
${ }^{1}$ Universitas Negeri Jakarta, Indonesia \\ ${ }^{2}$ Universitas Islam Negeri Raden Intan Lampung, Indonesia \\ paud13.trinita@gmail.com
}

\begin{abstract}
In the 21 st century, children to adults are digital consumers to the use of technology, it even various studies explain that a lot of children in the age of two are now accustomed to using gadgets to play games, open YouTube or watch video from galleries with great expertise. The goal of this article study was to explore the habits of using gadgets in early childhood and cases of early childhood viewing porn videos, to analisys the impact of children watching pornography, and to find the causes of early childhood exposure to pornographic videos in today's digital era. This article contains used qualitative descriptive approach with library research method. The data were collected by analyzing some printed and electronic journals, books, documents, and other sources that related. These results indicated that exposure pornography in children can cause the brain demage, impaired concentration and focus ability, and become addicted to pornographic videos, experience sexual deviations, and become perpetrators of sexual harassment or violence in the future.
\end{abstract}

Keywords: Early childhood, impact of technology, internet, pornography.

\begin{abstract}
Abstrak
Pada abad 21, anak usia dini hingga manula sudah terbiasa dengan penggunaan teknologi, bahkan beberapa penelitian menjelaskan bahwa anak usia dua tahun saat ini sudah terbiasa menggunakan gadget untuk bermain game, membuka youtube atau membuka galeri video dengan sangat ahli. Oleh karena itu, artikel ini bertujuan untuk mengeksplorasi tentang kebiasaan penggunaan gadget pada anak usia dini dan kasus-kasus anak usia dini melihat video porno, mencari dampak anak melihat pornografi, dan penyebab anak usia dini terpapar video porno di era digital saat ini. Artikel ini menggunakan pendekatan kualitatif deskriptif dengan metode tinjauan literatur. Data dikumpulkan dengan menganalisis beberapa kasus, jurnal, dokumen, data lain baik cetak maupun elektronik yang relevan. Hasil menunjukkan bahwa paparan pornografi pada anak dapat menyebabkan kerusakan otak, rusak kemampuan konsentrasi dan fokus, serta membuat anak kecanduan video porno, mengalami penyimpangan seks, hingga menjadi pelaku pelecehan atau kekerasan seksual di masa mendatang.
\end{abstract}

Kata kunci: anak usia dini, dampak teknologi, internet, pornografi. 


\section{PENDAHULUAN}

Indonesia saat ini sedang memasuki era revolusi industri 4.0, dimana terjadi pengembangan teknologi yang semakin canggih. Seluruh elemen bangsa Indonesia tanpa terkecuali merasakan dampak positif dari terciptanya teknologi-teknologi baru yang bertujuan untuk mempermudah segala aktivitas manusia dan menjadi penikmat teknologi. Survei terakhir APJII (Asosiasi Penyelenggara Jasa Internet Indonesia) menjelaskan bahwa sepanjang tahun 2017 pengguna internet di Indonesia (diatas 13 tahun) mengalami pertumbuhan, dari total 262 juta jiwa, sebanyak 143,26 juta $(54,68 \%)$ orang dari populasi Indonesia saat ini sudah dapat mengakses internet. Data tersebut mengalami peningkatan sekitar 9,5juta pada tahun 2018, pada akhir tahun 2019 ini pengguna internet di Indonesia menembus angka 175,4 juta (64\%) dari total penduduk 272 juta (Asosiasi Penyelenggara Jasa Internet Indonesia, 2017; Ayuwuragil, 2018), dan dipastikan terus meningkat pada 2020, khususnya karena wabah virus covid-19 yang terus meningkat ini.

Penggunaan Internet memungkinkan seluruh penggunanya mendapatkan segala informasi yang diinginkannya. Baik untuk memperoleh pengetahuan, informasi, atau keterampilan baru. Internet juga dapat membuat komunikasi dengan teman dan keluarga yang jauh maupun dekat lebih cepat dan efisien. Peluang tersebut membuat manusia membutuhkan bahkan semakin ketergantungan pada teknologi dan internet di setiap waktu, bukan hanya untuk orang dewasa, namun juga untuk para orangtua.

Children's and Parents': Media Use and Attitudes Report 2017 di Inggris memberikan informasi bahwa anak usia 3-7 tahun telah mulai menggunakan teknologi dan akses internet bahkan memiliki perangkat alat komunikasi (gadgetnya sendiri). Berdasarkan laporan tersebut, diketahui bahwa anak usia 3-4 tahun di Inggris sudah sangat terbiasa menggunakan teknologi, sebagai berikut $22 \%$ anak memiliki gadget nya sendiri (1\% smartphone, dan $21 \%$ tablet); $96 \%$ anak menonton TV sekitar 15 jam per minggu; $41 \%$ anak menonton TV di perangkat lain (banyak menggunakan tablet); $40 \%$ anak bermain games sekitar 6 jam per minggu; 53\% anak online sekitar 8 jam per minggu; $71 \%$ dapat menggunakan tabletnya untuk online; $48 \%$ dapat membuka dan mencari video di Youtube (Ofcom, 2017).

Lebih lanjut, diketahui bahwa anak usia 5-7 tahun di Inggris sudah sangat terbiasa menggunakan teknologi, sebagai berikut $40 \%$ anak memiliki gadget nya sendiri (5\% smartphone, dan 35\% tablet); $95 \%$ anak menonton TV sekitar 13,5 jam per minggu; $49 \%$ anak menonton TV di perangkat lain (banyak menggunakan tablet); 66\% anak bermain games sekitar 7,5 jam per minggu; $79 \%$ anak online sekitar 9 jam per minggu; 63\% dapat menggunakan tabletnya untuk online; $71 \%$ dapat membuka dan mencari video di Youtube; $3 \%$ bahkan sudah memiliki social medianya sendiri. Data di atas menunjukkan bahwa anak usia dini di abad 21 sudah sangat beradaptasi dan terbiasa dengan teknologi saat ini (Ofcom, 2017).

Bukan hanya di Inggris, tapi anak usia dini di Indonesia saat ini pun sudah cukup familiar dengan penggunaan perangkat smartphone ataupun tablet (Haryanto, 2020; Sigman, 2017). Hal ini dibuktikan dengan seringnya kita temui di lingkungan kita orangtua bahkan dengan sengaja memberikan anaknya gadget untuk membuat anak diam dan berhenti meminta atau melakukan sesuatu. Padahal saat terhubung dengan internet, anak sangat mungkin terpapar hal-hal berbau pornografi yang dapat memberikan dampak negatif pada perkembangannya (Saint John Vianney Centre, 2018). Berdasarkan argumen tersebut di atas, peneliti tertarik untuk melakukan studi pustaka tentang Dampak Video Porno pada Anak Usia Dini. 


\section{METODE PENELITIAN}

Metode yang digunakan dalam kajian ini menggunakan pendekatan kualitatif deskriptif dengan metode studi pustaka tinjauan literatur. Pengumpulan data yang digunakan dalam penelitian ini adalah dengan menganalisis berbagai sumber informasi yang relevan dengan kajian ini. Sumber data yang digunakan peneliti dalam kajian ini dalah sumber data sekunder, yaitu berupa data dan informasi penunjang tambahan yang berasal dari berbagai sumber atau literatur, seperti berita kasus kekerasan yang terjadi di Indonesia, teori dari buku teks, majalah atau publikasi ilmiah, hasil penelitian dari penelitian terdahulu, dokumen-dokumen pendukung, serta sumber-sumber data dan atau informasi lainnya yang dianggap relevan dengan penelitian atau kajian.

\section{HASIL DAN PEMBAHASAN}

A. Pandangan Orangtua Terhadap Penggunaan Gadget di Era Digital

Realitas pesatnya perkembangan teknologi di Indonesia saat ini mempengaruhi cara anak saat ini tumbuh, belajar, bermain, dan berinteraksi. Anak-anak abad 21 yang lahir di era revolusi industri 4.0 tumbuh dengan platform digital seperti Facebook, Twitter, Instagram dan YouTube, penelitian terbaru menjelaskan bahwa anak berusia 2 tahun sudah tahu dan mampu menggunakan tablet sebelum mereka dapat berbicara, Studi bahkan $40 \%$ anak usia 2 sampai 4 tahun menggunakan ponsel pintar, iPod, iPad atau sejenisnya (Graafland, 2018).

Perkembangan zaman (modernisasi) adalah sebuah kepastian. Orang tua tidak dapat membatasi diri kita atau anak-anak untuk menjauh dari teknologi canggih saat ini, karena itu dapat membuat anak usia dini tertinggal jauh oleh dunia yang terus berkembang (Sundus, 2018). Meskipun American Academy of Pediatrics (AAP) pun mengeluarkan Policy Statement tentang penggunaan media pada anak, AAP merekomendasikan agar para orang tua untuk mempertimbangkan penggunaan media untuk bayi karena secara potensial dampak negatif penggunaan media jauh lebih besar (American Academy of Paediatrics, 2011). Namun Northwestern University melakukan sebuah survey pada orangtua anak usia 0-8 tahun di California dan Illinois dan menemukan bahwa: 13\% orang tua sangat khawatir dengan konten yang anak mereka gunakan, lalu 17\% agak khawatir, (13\% dari 17\% mengatakan agak khawatir mengingat usia anak mereka); dan 55\% orang tua tidak khawatir. Survei lainnya menjelaskan bahwa lima puluh tujuh persen (57\%) orang tua mengatakan mereka tidak khawatir tentang anakanak mereka kecanduan media "baru", dan empat puluh persen (40\%) mengatakan mereka khawatir tentang hal itu. Survei diatas menjelaskan bahwa masih banyak orang tua yang tidak keberatan, bahkan mendukung penggunaan gadget dan tidak peduli terkait penggunaan media pada anak-anaknya (Wartella et al., 2014).

\section{B. Anak Terpapar Pornografi}

Pornografi didefinisikan sebagai semua bentuk media eksplisit yang menampilan yang mengekspos budaya atau keragaman hubungan yang sangat seksual, seperti menunjukkan alat 
kelamin dan kegiatan seksual secara terbuka (tanpa disembunyikan), dimana tujuan utamanya adalah untuk membangkitkan gairah orang yang melihat (American Psychological Association, 2007; Malamuth et al., 2001; Peter \& Valkenburg, 2007). Sebuah survey Institute for Public Policy Research (IPPR) menjelaskan bahwa dari 500 remaja , diketahui bahwa $77 \%$ anak lakilaki dan $83 \%$ anak perempuan mengakui bahwa sangat mudah bagi kaum muda untuk secara tidak sengaja melihat pornografi saat mereka dengan terhubung internet (Saint John Vianney Centre, 2018).

Sebuah kasus terkait paparan pornografi pernah terjadi pada pertengahan bulan maret 2018, masyarakat Indonesia di sedihkan dengan munculnya video anak perempuan berusia 5 tahun yang duduk di samping ibunya sedang serius menonton video porno di ruang tunggu Kantor Samsat Kebon Nanas, Jakarta Timur (Miftahul Munir, 2018; Pranamya Dewati, 2018). Penelitian mengenai pornografi (Bulkley, 2013) menunjukkan bahwa pada tahun 2013 usia ratarata seorang anak pertama kali melihat pornografi internet adalah 11 tahun, dimana terdapat sebanyak $70 \%$ anak laki-laki telah menghabiskan setidaknya 30 menit berturut-turut melihat pornografi on-line setidaknya pada satu kesempatan; 35\% anak laki-laki telah melakukan ini setidaknya sepuluh kali; $83 \%$ anak laki-laki telah melihat seks berkelompok di internet; $67 \%$ anak-anak mengaku membersihkan sejarah internet mereka untuk menyembunyikan aktivitas online mereka; $0 \%$ pengguna pornografi melaporkan kecanduan.

Direktorat Pembinaan Pendidikan Keluarga Kementerian Pendidikan dan Kebudayaan menjelaskan bahwa kemajuan teknologi informasi dan komunikasi memengaruhi jumlah anakanak yang terpapar video porno, dan biasanya video porno dapat dengan mudah ditemukan anak di game, majalah, media sosial, dan jejaring internet (Direktorat Pembinaan Pendidikan Keluarga, 2017).

\section{Faktor-Faktor Penyebab Anak Terpapar Video Porno}

Beberapa literatur menjelaskan bahwa terdapat beberapa faktor yang menyebabkan anak terpapar pornografi (Direktorat Pembinaan Pendidikan Keluarga, 2017; Semai, 2015; Strasburger et al., 2010; Tim Sejiwa, 2018), antara lain: 1) tidak sengaja melihat pornografi yang muncul saat menggunakan gadget orangtua atau saat mengakses internet; 2) menerima dan membuka pesan teks, foto, atau video seksual di media sosial; 3) memiliki rasa ingin tahu atau penasaran yang tinggi, sehingga membuat anak mencoba mengakses situs bermuatan pornografi; 4) terpengaruh dengan ajakan atau bujuk rayu teman sebaya dan lingkungan sekitarnya; 5) perasaan BLAST, yaitu: Bored (Jenuh), Lonely (Kesepian), Angry (Marah), Stressed (Stres), Tired (Lelah); 6) kurang pendidikan agama, khususnya pembelajaran karakter dan penanaman akhlak dari sekolah; 7) kurangnya kesadaran orang tua terhadap pentingnya perhatian orang tua dalam pengawasan media yang digunakan anak.

\section{Dampak Negatif Paparan Pornografi pada Anak}

Kemajuan teknologi ibarat dua mata pisau, di satu sisi sangat menguntungkan, di sisi lain bisa berbahaya. Para peneliti ahli sosial, psikologi klinis telah banyak mengklarifikasi beberapa dampak social, psikologis. Sedangkan peneliti biologi dan ahli syaraf mulai menggambarkan bagaimana pornografi memili dampak negatif yang kuat yang sangat berbahaya untuk generasi muda (Fagan, 2009). Survei Northwestern University (Wartella et al., 2014) menjelaskan bahwa 
orangtua anak berusia 0-8 tahun yang terlibat dalam survey percaya bahwa setiap media memiliki efek positif atau negatif yang cukup signifikan terhadap anak, diantaraya:

Tabel 1. Persentase Opini Orangtua tentang Dampak Penggunaan Gadget pada Anak Usia 0-8 Tahun

\begin{tabular}{lcc} 
& Positif & Negatif \\
\hline Kemampuan Membaca & $36 \%$ & $22 \%$ \\
Kemampuan Matematika & $31 \%$ & $23 \%$ \\
Kemampuan Berbicara & $21 \%$ & $28 \%$ \\
Kemampuan Sosial & $16 \%$ & $39 \%$ \\
Kemampuan Fisik & $8 \%$ & $54 \%$ \\
Kemampuan Fokus & $19 \%$ & $38 \%$ \\
Kreatifitas & $31 \%$ & $27 \%$ \\
Tingkah Laku & $12 \%$ & $30 \%$ \\
\hline
\end{tabular}

Sumber : Survei Northwestern University

Meskipun terdapat cukup banyak penelitian yang menunjukkan aspek positif dari teknologi modern, namun banyak juga pula penelitian yang menunjukkan bahwa teknologi modern memiliki efek yang merugikan anak. Salah satu dampak negatif dari kemajuan teknologi adalah merebaknya pornografi (Dehmler, 2009; Simuforosa, 2013; Suyatno, 2011). Menurut para ahli pornografi memiliki begitu banyak dampak negatif untuk anak, adapun kemungkinan negatif dari paparan pornografi khususnya video porno pada anak usia dini, diantaranya adalah:

\section{Merusak Otak}

Professor Greenfield dari Oxford University menjelaskan bahwa otak adalah organ manusia yang dapat berubah. Otak secara substansial dapat dibentuk oleh pengalaman atau dengan hal-hal yang kita lakukan. Pada tingkat mikroseluler, jaringan sel-sel saraf yang membentuk bagian-bagian otak sebenarnya berubah sebagai respons terhadap pengalaman dan rangsangan tertentu (Greenfield, 2008; Sherwood \& Smaers, 2013; Verendeev \& Sherwood, 2017). Dengan kata lain, otak sebenarnya bisa dibentuk, terutama pada masa usia dini. Dampak kecanduan pornografi ini sama seperti penggunaan obat-obatan terlarang yang dapat merusak otak dan pikiran, dimana saat seseorang melihat konten pornografi, struktur kerangka otak dapat berubah dengan penyusutan jaringan otak, lambat laun otak akan mengalami pengecilan ukuran dan kerusakan permanen pada bagian Pre Frontal Cortex (PFC).

Peneliti otak menjelaskan bahwa PFC hanya ada pada otak manusia, yg membedakan otak manusia dengan otak binatang. PFC ini berfungsi berfungsi menggabungkan informasi dari semua indera dan membentuk kepribadian dan perilaku social manusia, sehingga manusia berbahasa, berimajinasi, melakukan penilaian (baik dan buruk atau benar dan salah), mengambilan keputusan seperti apa ia harus bersikap atau bertindak, serta merancang masa depan (Sherwood \& Smaers, 2013; Smaers et al., 2017; Tim Sejiwa, 2018). Saat melihat konten porno pertama kali, biasanya anak akan merasa jijik dan tidak pantas karena aktifnya sistem limbik di otak. Saat sistem limbik aktif, sistem lain dalam otak (norepinefrin dan serotonin) pun ikut aktif. Sistem tersebut menimbulkan dorongan pada sistem limbik untuk meningkatkan perasaan nyaman, bahagia, puas, sehingga meningkatkan nafsu serta dorongan 
seksual untuk. Jika hal-hal diatas tidak dibatasi atau didapat secara berlebihan, ia akan membuat seseorang kecanduan (Kamaruddin et al., 2018; Love et al., 2015).

\section{Membuat Anak Kecanduan Pornografi}

Montessori pernah menyatakan bahwa masa usia dini merupakan periode sensitif, selama masa inilah anak usia dini dengan mudah menerima stimulus-stimulus dari lingkungannya, dimana kemampuan otak anak dalam menerima semua pengetahuan dari lingkungannya diikuti dengan rasa ingin tahu yang tinggi (Hainstock \& Havis, 1997). Rasa ingin tahu anak usia dini ini merupakan bukti bahwa anak adalah pembelajar aktif, hal dapat dilihat sejak adanya inisiatif anak untuk mencari tahu, mencoba dan bereksporasi secara mandiri semua hal baru atau hal yang menarik baginya (Anggraini, 2017; Walin et al., 2016). Oleh karena itu, tidak menutup kemungikinan jika salah satu hal yang mungkin membuat anak tertarik adalah pornografi atau video porno yang secara tidak sengaja ditontonnya.

Awalnya mayoritas anak-anak terpapar pornografi secara tidak sengaja, namun seperti yang telah dijelaskan sebelumnya, video porno dapat mengubah bagian otak anak sehingga dapat membuat orang yang melihatnya kecanduan, dan menginginkan untuk melihat pornografi itu kembali secara sengaja. Mendukung pernyataan diatas, banyak peneliti yang menjelaskan bahwa pornografi dapat membuat seseorang kecanduan, dimana banyak anakanak yang tidak sengaja melihat konten porno untuk pertama kali akan terdorong untuk melihat lagi dengan sengaja melihat, bahkan besar kemungkinannya bahwa anak akan mengkonsumsi konten porno berulang-ulang atau bahkan seumur hidupnya (Semai, 2015). Hal ini biasa juga disebut dengan narkolema (narkotika lewat mata). Narkolema (narkotika lewat mata) adalah pornografi yang dilihat oleh seseorang yang memiliki efek kecanduan dan daya rusak sebagaimana pada pengguna narkotika (Purwaningsih, 2018). Narkolema ini dapat mempengaruhi konsentrasi anak yang kecanduan pornografi terus membayangkan materi pornografi yang sebelumnya anak lihat dan merasa ingin melihat atau menikmati konten pornografi lagi. Sebuah penelitian mendapati bahwa dari 162 siswa yang terpapar pornografi, hanya 59 siswa $(37,42 \%)$ yang dengan tegas menjawab tidak mau lagi melihat konten pornografi (Purwaningsih, 2018; Suyatno, 2011).

Berdasarkan gender, diketahui bahwa anak laki-laki lebih cenderung lebih mudah kecanduan pornografi dibandingkan dengan perempuan. Hal ini diperkuat dengan hasil penelitian yang menunjukkan bahwa anak perempuan merasa kecewa melihat konten porno. Sebagian besar mengatakan bahwa anak perempian merasa malu, jijik, serta mengatakan bahwa itu adalah hal "bodoh", "kasar" dan "merendahkan wanita", sedangkan sebagian besar mengaku telah melihat pornografi online dan merasakan kegembiraan seksual jika melihat lebih banyak lagi, hanya 6\% anak laki-laki yang melapor merasa kecewa dengan yang dilihatnya (Abiala \& Hernwall, 2013; Arrington-Sanders et al., 2015; Flood, 2009).

\section{Sulit Konsentrasi dan Fokus}

Dampak kecanduan pornografi pada anak yang memiliki IQ tinggi adalah dapat mengakibatkan anak sulit berkonsentrasi untuk belajar dan beraktivitas karena anak akan gelisah akibat rasa penasaran dan ingin tahu anak yang besar. Sedangkan untuk anak yang ber-IQ rendah, pengaruhnya bisa lebih ekstrim lagi, mereka tidak akan mampu berkonsentrasi lagi dan hari-harinya total dikuasai kegelisahan dan pikiran tentang konten porno yang dilihatnya. Pornografi yang ditonton anak pada masa golden age merupakan sensasi seksual 
yang diterima sebelum waktunya, sehingga yang terjadi adalah mengendapnya kesan mendalam di bawah otak sadar yang bisa membuat anak selalu memikirkan konten porno, mereka sulit konsentrasi, tidak fokus, malas belajar, tidak bergairah melakukan aktivitas lain, dan hingga mengalami disorientasi (kehilangan pandangan) terhadap jati diri bahwa sebenarnya mereka masih anak-anak. (Haryani R. et al., 2012).

Penelitian lain menunjukkan bahwa pornografi dapat mempengaruhi konsentrasi belajar, dimana dimasa mendatang anak yang kecanduan pornografi akan terbayang-bayang dengan materi porno yang di lihatnya. Dimana terdapat sebanyak $20.37 \%$ anak menganggap bahwa pornografi mengganggu konsentrasi belajar dan $22.22 \%$ siswa kadang-kadang merasa bahwa pornografi mengganggu konsentrasi belajar mereka. Sulitnya anak untuk berkonsentrasi membuat anak tidak bisa fokus saat belajar, karena merasa kegiatan belajar membosankan dan tidak memberikan rasa senang atau puas, seperti saat anak menonton video porno. Hal ini dapat menyebabkan anak menjadi susah fokus, tidak mau memperhatikan apa yang diajarkan guru dan asik sendiri dengan pikiran tentang pornografi, dan menyebabkan konsentrasi anak menjadi lebih pendek, sulit berkonsentrasi saat belajar, dan tentunya berdampak pada penurunan prestasi anak di sekolah (Febrino, 2017; Nahriyah, 2017; Suyatno, 2011).

\section{Memungkinkan Anak Menjadi Pelaku Kekerasan Seksual di Masa Mendatang}

Sifat dasar anak-anak adalah meniru. Mereka akan meniru yang dilihatnya. Beberapa penelitian menjelaskan bahwa kebiasaan negatif anak yang sudah melihat pornografi adalah melihat gambar atau tayangan porno (blue film) karena rasa ingin tahunya yang besar (Anggraini, 2017; Diana \& Meyritha, 2019; Suyatno, 2011). Setelah anak terbiasa dan kecanduan melihat hal-hal pornografi, anak akan membiasakan diri melakukan hal-hal yang dilihatnya tersebut tanpa merasa bersalah, atau bahkan bangga dan merasa hal itu "modern" atau "keren" (Gunawan, 2016).

Jika pornografi meracuni mereka, bukan hanya akan menimbulkan kecanduan, namun anakpun sangat mungkin menjadi pelaku kekerasan seksual dengan melakukan aktifitas seksual yang mereka lihat kepada anak yang lebih muda, bahkan teman sebayanya yang lebih lemah (Diana \& Meyritha, 2019; Novita, 2018). Peniruan perilaku ini dapat berupa perilaku hubungan seksual baik yang ringan seperti ciuman, pelukan, hingga perilaku seksual berat seperti berhubungan intim (Yutifa et al., 2015).

Seperti yang terjadi pada pertengahan bulan maret 2017 lalu, enam orang anak lakilaki berusia 6 sampai 12 tahun diduga telah melakukan pelecehan seksual terhadap anak berusia 8 tahun di Bogor karena dipengaruhi tontonan film porno yang disuguhi oleh seorang pemuda berusia 24 tahun setempat berinisial M (Bempah, 2018). Pada akhir tahun 2017, penulis menemukan kasus di masyarakat bahwa seorang anak usia 8 tahun melakukan pelecehan seksual pada saudaranya yang berusia 6 tahun di Bandar Lampung karena mempraktekkan video porno yang di tontonnya, namun kasus ini tidak dilaporkan oleh orangtua kedua belah pihak karena orangtua bingung dan merasa takut. Bukannya tidak mungkin, hal-hal yang sama terjadi pada anak-anak lain di daerah yang masih menganggap hal seperti ini merupakan hal tabu dan memalukan. 


\section{SIMPULAN DAN SARAN}

Penggunaan Internet memungkinkan seluruh penggunanya mendapatkan segala informasi yang diinginkannya. Baik untuk memperoleh pengetahuan, informasi, atau keterampilan baru, berkomunikasi dengan teman dan keluarga yang jauh dengan lebih cepat dan efisien. Dan peluang tersebut membuat manusia membutuhkan bahkan semakin ketergantungan pada teknologi dan internet di setiap waktu, bukan hanya untuk orang dewasa, namun juga untuk para orangtua. Pandangan orangtua terhadap penggunaan gadget di era digital saat ini sangat mempengaruhi cara anak tumbuh, belajar, bermain, dan berinteraksi.

Setiap keluarga tidak dapat membatasi anaknya untuk menghindari teknologi hal tersebut dapat membuat anak usia dini tertinggal jauh oleh dunia yang terus berkembang. Meskipun American Academy of Pediatrics pun mengeluarkan Policy Statement tentang penggunaan media pada anak, AAP merekomendasikan agar para orang tua untuk mempertimbangkan penggunaan media untuk bayi karena secara potensial dampak negatif penggunaan media jauh lebih besar. Namun Northwestern University melakukan sebuah survey pada orangtua anak usia 0-8 tahun di California dan Illinois. Survei diatas menjelaskan bahwa masih banyak orang tua yang mendukung penggunaan gadget dan tidak peduli terkait penggunaan media pada anak-anaknya.

Pornografi didefinisikan sebagai semua bentuk media eksplisit yang menampilan yang mengekspos budaya atau keragaman hubungan yang sangat seksual, seperti menunjukkan alat kelamin dan kegiatan seksual secara terbuka (tanpa disembunyikan), dimana tujuan utamanya adalah untuk membangkitkan gairah orang yang melihat.

Sebuah survey Institute for Public Policy Research (IPPR) menjelaskan bahwa dari 500 remaja, diketahui bahwa $77 \%$ anak laki-laki dan $83 \%$ anak perempuan mengakui bahwa sangat mudah bagi kaum muda untuk secara tidak sengaja melihat pornografi saat terhubung internet. Penelitian lain mengenai remaja dan porno menunjukkan bahwa $93 \%$ anak laki-laki dan $62 \%$ anak perempuan terpapar pornografi dari internet sebelum usia 18 tahun, 70\% anak laki-laki telah menghabiskan setidaknya 30 menit berturut-turut melihat pornografi online setidaknya pada satu kesempatan, 35\% anak laki-laki telah melakukan ini setidaknya sepuluh kali, 83\% anak laki-laki telah melihat seks berkelompok di internet, 67\% anak-anak mengaku membersihkan sejarah internet mereka untuk menyembunyikan aktivitas online mereka, dan $0 \%$ pengguna pornografi melaporkan kecanduan.

Direktorat Pembinaan Pendidikan Keluarga Kementerian Pendidikan dan Kebudayaan menjelaskan bahwa kemajuan teknologi informasi dan komunikasi memengaruhi jumlah anak yang terpapar video porno, dan biasanya video porno dapat dengan mudah ditemukan anak di game, majalah, media sosial, dan jejaring internet. Beberapa faktor yang menyebabkan anak terlibat pornografi diantaranya: 1) Tidak sengaja melihat pornografi yang muncul saat menggunakan gadget orangtua atau saat mengakses internet; 2) Menerima pesan teks, foto, atau video seksual di media social; 3) Rasa ingin tahu atau penasaran yang tinggi, sehingga membuat anak mencoba mengakses situs bermuatan pornografi; 4) Terpengaruh dengan ajakan atau bujuk rayu teman sebaya dan lingkungan sekitarnya; 5) Perasaan BLAST, yaitu: Bored (Jenuh), Lonely 
(Kesepian), Angry (Marah), Stressed (Stres), Tired (Lelah); 5) Kurang pendidikan agama terkait pembelajaran karakter dan penanaman akhlak dari sekolah; 6) kurangnya kesadaran orang tua terhadap pentingnya memperhatikan dan mengawasi anak saat menggunakan gadget.

Para ahli pornografi menjelaskan bahwa terdapat begitu banyak dampak negatif pornografi untuk anak, adapun kemungkinan negatif dari paparan pornografi khususnya video porno pada anak usia dini, diantaranya adalah; 1) Merusak Otak, 2) Membuat Anak Kecanduan Pornografi, 3) Sulit Konsentrasi dan Fokus, 4) Memungkinkan Anak Menjadi Pelaku Kekerasan Seksual di Masa Mendatang karena sifat dasar anak-anak adalah meniru apa pun yang dilihatnya. Beberapa penelitian menjelaskan bahwa kebiasaan negatif anak yang sudah melihat pornografi adalah melihat gambar atau tayangan porno (blue film) karena rasa ingin tahunya yang besar.

Pengawasan dari orang dewasa sangat dibutuhkan anak, karena pengalaman yang tidak tepat pada anak dapat mengembangkan persepsi yang salah tentang pornografi pada anak, dan hal ini dapat membuat anak kecanduan video porno, mengalami penyimpangan seks, hingga menjadi pelaku pelecehan atau kekerasan seksual di masa mendatang.

\section{DAFTAR PUSTAKA}

Abiala, K., \& Hernwall, P. (2013). Tweens negotiating identity online - Swedish girls' and boys' reflections on online experiences. Journal of Youth Studies, 16(8), 951-969. https://doi.org/10.1080/13676261.2013.780124

American Psychological Association. (2007). Task Force on the Sexualization of Girls. In Report of the APA Task Force on the Sexualization of Girls.

Anggraini, Trinita. (2017). Pendidikan Seksual Anak Usia Dini : Aku dan Diriku. Jurnal Pendidikan Anak, 3 (2).

Anggraini, W., \& Kuswanto, C. W. (2019). Teknik Ceklist Sebagai Asesmen Perkembangan Sosial Emosional di RA. Al-Athfaal: Jurnal Ilmiah Pendidikan Anak Usia Dini, 2(2), 61-70. https://doi.org/10.24042/ajipaud.v2i2.5248

Arrington-Sanders, R., Harper, G. W., Morgan, A., Ogunbajo, A., Trent, M., \& Fortenberry, J. D. (2015). The Role of Sexually Explicit Material in the Sexual Development of Same-SexAttracted Black Adolescent Males. Archives of Sexual Behavior, 44(3), 597-608. https://doi.org/10.1007/s10508-014-0416-x

Asosiasi Penyelenggara Jasa Internet Indonesia. (2017). Infografis Penetrasi \& Perilaku Pengguna Internet Indonesia: Survey 2017.

Ayuwuragil, K. (2018). Pengguna Internet Indonesia Capai 143 Juta. CNN Indonesia. https://www.cnnindonesia.com/teknologi/20180219160127-192-277197/pengguna-internetindonesia-capai-143-juta

Bempah, R. T. (2018). Dipengaruhi Film Porno, 6 Bocah di Bawah Umur Diduga Setubuhi Gadis 8 Tahun. Kompas.Com. https://kilasdaerah.kompas.com/jawatengah/read/2018/03/05/13102921/dipengaruhi-film-porno-6-bocah-di-bawah-umur-didugasetubuhi-gadis-8-tahun 
Bulkley, M. (2013). Warning to parents: cyber-sex addiction is a teen issue. Family Bootcamp. http://familybootcamp.org/news/2013/11/1/warning-to-parents-cyber-sex-addiction-is-ateen-issue

Dehmler, K. (2009). Adolescent technology usage during sleep-time: Does it influence their quality of sleep, attention difficulties and academic performance? [Rochester Institute of Technology]. In Rochester Institute of Technology. https://doi.org/http://dx.doi.org/10.2471/BLT.14.147231

Diana, I., \& Meyritha, T. (2019). Studi Kasus Kecanduan Pornografi pada Remaja. Motiva, 1(1).

Direktorat Pembinaan Pendidikan Keluarga. (2017). Seri Pendidikan Orang Tua: Mendampingi Anak Menghadapi Bahaya Pornografi. Direktorat Pembinaan Pendidikan Keluarga.

Fagan, P. F. (2009). the Effects of Pornography on. Research Synthesis, December.

Febrino. (2017). Tindakan Preventif Pengaruh Negatif Gadget Terhadap Anak. Noura, 1(1), 1-2.

Flood, M. (2009). The Harms of Pornography Exposure Among Children and Young People. Child Abuse Review, 18(6), 384-400. https://doi.org/10.1002/car.1092

Graafland, J. H. (2018). New Technologies and 21st Century Children. OECD Education Working Papers, 179. https://doi.org/10.1787/e071a505-en

Greenfield, S. (2008). Modern technology is changing the way our brains work, says neuroscientist | Daily Mail Online. Daily Mail.

https://www.dailymail.co.uk/sciencetech/article-565207/Modern-technology-changing-waybrains-work-says-neuroscientist.html

Gunawan, A. (2016). Pengaruh Kegiatan Matrikulasi Pendidikan Seks dan Kesadaran Tentang Bahaya Pornografi Terhadap Karakter Peserta Didik. Tsamrah Al-Fikri, 10(1), 155-172.

Hainstock, E. G., \& Havis, L. (1997). Teaching Montessori in the Home: The Pre-School Years (p. 115). Plume.

Haryani R., M., Mudjiran, \& Syukur, Y. (2012). Dampak Pornografi terhadap Perilaku Siswa dan Upaya Guru Pembimbing Untuk Mengatasinya. Konselor: Jurnal Ilmiah Konseling, 1(1), 1-8. https://doi.org/10.1016/j.jvolgeores.2007.11.022

Haryanto, A. T. (2020, February 20). Riset: Ada 175,2 Juta Pengguna Internet di Indonesia. Detikinet. https://inet.detik.com/cyberlife/d-4907674/riset-ada-1752-juta-pengguna-internetdi-indonesia

Kamaruddin, N., Rahman, A. W. A., \& Handiyani, D. (2018). Pornography addiction detection based on neurophysiological computational approach. Indonesian Journal of Electrical Engineering and Computer Science, 10(1), 138-145. https://doi.org/10.11591/ijeecs.v10.i1.pp138-145

Kuswanto, C. W. (2016). Menumbuhkan Kemandirian Anak Usia Dini Melalui Bermain. Jurnal Ilmiah Pendidikan Islam Anak Usia Dini Darul Ilmi, 1(2). 
Love, T., Laier, C., Brand, M., Hatch, L., \& Hajela, R. (2015). Neuroscience of internet pornography addiction: A review and update. Behavioral Sciences, 5(3), 388-433. https://doi.org/10.3390/bs5030388

Malamuth, N., Donnerstein, E., \& Smith, S. (2001). Research on sex in the media: what do we know about effects on children and adolescents? In D. G. Singer (Ed.), Handbook of Children and the Media (pp. 269-287). SAGE.

Miftahul Munir. (2018). Viral, Bocah Nonton Video Porno, Orang Tua Cuek. Akurat.Co. https://akurat.co/id-175111-read-viral-bocah-nonton-video-porno-orang-tua-cuek

Nahriyah, S. (2017). Tumbuh Kembang Anak Di Era Digital. Risalah: Jurnal Pendidikan Dan Studi Islam, 4(1), 65-74. https://doi.org/10.5281/zenodo.1227474

Novita, E. (2018). Faktor-Faktor yang Mempengaruhi Kebiasaan Menonton Film Porno pada Remaja. ANTHROPOS : Jurnal Antropologi Sosial Dan Budaya, 4(1), 31-44.

Ofcom. (2017). Children and Parents : Media Use and Attitudes Report.

Peter, J., \& Valkenburg, P. M. (2007). Adolescents' Exposure to a Sexualized Media Environment and Their Notions of Women as Sex Objects. Sex Roles, 56, 381-395. https://doi.org/10.1007/s11199-006-9176-y

Pranamya Dewati. (2018). Kemen PPPA Siap Beri Trauma Healing pada Anak yang Tonton Video Porno. Kumparan.Com. https://kumparan.com/@ kumparannews/kemen-pppa-siapberi-trauma-healing-pada-anak-yang-tonton-video-porno

Purwaningsih, S. W. (2018). Pemberdayaan Remaja untuk Mencegah Narkolema. Gemassika, 2(1).

Saint John Vianney Centre. (2018). Understanding The Effects Of Pornography. Saint John Vianney Centre.

Semai. (2015). Bahaya Pornografi: Merusak Otak. Youtube. https://www.youtube.com/watch?v=O9rMmjVa5QI

Sherwood, C. C., \& Smaers, J. B. (2013). What's the fuss over human frontal lobe evolution? In Trends in Cognitive Sciences (Vol. 17, Issue 9, pp. 432-433). Elsevier Current Trends. https://doi.org/10.1016/j.tics.2013.06.008

Sigman, A. (2017). Screen Dependency Disorders: a new challenge for child neurology. Journal of the International Child Neurology Association, 17(119), 1-13.

Simuforosa, M. (2013). The impact of modern technology on the educational attainment of adolescents. International Journal of Education and Research, 1(9), 1-8.

Smaers, J. B., Gómez-Robles, A., Parks, A. N., \& Sherwood, C. C. (2017). Exceptional Evolutionary Expansion of Prefrontal Cortex in Great Apes and Humans. Current Biology, 27(5), 714-720. https://doi.org/10.1016/j.cub.2017.01.020

Strasburger, V. C., Jordan;, A. B., \& Donnerstein, E. (2010). Harmful effects of media on children and adolescents. Pediatrics, 125(4). https://doi.org/10.1542/peds.2009-2563 
Sundus, M. (2018). The Impact of using Gadgets on Children. S e s i r o p n e D afn od l A a $n$ $n r x i$ u e o t y J ISSN: 2167-1044 Journal of Depression and Anxiety, 7(1), 1-3. https://doi.org/10.4172/2167-1044.1000296

Suyatno, T. (2011). Pengaruh Pornografi Terhadap Perilaku Belajar Siswa. Jurnal Pendidikan Dompet Dhuafa, 1, 1-12.

Tim Sejiwa. (2018). Smart School Online: Hari-Hari Tanpa Pornografi. Smart School Online.

Verendeev, A., \& Sherwood, C. C. (2017). Human Brain Evolution. In Current Opinion in Behavioral Sciences (Vol. 16, pp. 41-45). Elsevier Ltd.

https://doi.org/10.1016/j.cobeha.2017.02.003

Walin, H., O'grady, S., \& Xu, F. (2016). Curiosity and Its Influence on Children's Memory.

Wartella, E., Rideout, V., Lauicella, A. R., \& Connell, S. L. (2014). Revised Parenting in the Age of Digital Technology: A National Survey (Issue June).

Yutifa, H., Dewi, A. P., \& Misrawati. (2015). Hubungan Paparan Pornografi Melalui Elektronik Terhadap Perilaku Seksual Remaja. Jom, 2(2). 